\title{
Correction to: Antibiotic prescriptions and risk factors for antimicrobial resistance in patients hospitalized with urinary tract infection: a matched case-control study using the French health insurance database (SNDS)
}

\author{
Marion Opatowski ${ }^{1,2}$, Christian Brun-Buisson ${ }^{1,2}$, Mehdi Touat ${ }^{1,2}$, Jérôme Salomon 1,2,3, Didier Guillemot ${ }^{1,2,3}$, \\ Philippe Tuppin ${ }^{4}$ and Laurence Watier ${ }^{1,2^{*}}$
}

Correction to: BMC Infect Dis 21, 571 (2021)

https://doi.org/10.1186/s12879-021-06287-1

Following publication of the original article [1], the authors identified an error in the Supplementary file. The revised and correct version of the Supplementary file is given below:

Furthermore, a typo was found in an author's affiliation.

The incorrect affiliation name is:

Center for Research in Epidemiology and Population Health ou (CESP), INSERM U1018, Paris-Saclay University, UVSQ, Montigny-Le-Bretonneux, France

The correct affiliation name is:

Center for Research in Epidemiology and Population Health (CESP), INSERM U1018, Paris-Saclay University, UVSQ, Montigny-Le-Bretonneux, France

The original article has been corrected as well.

\section{Supplementary Information}

The online version contains supplementary material available at https:/doi. org/10.1186/s12879-021-06329-8.

\footnotetext{
The original article can be found online at https://doi.org/10.1186/s12879021-06287-1.

* Correspondence: laurence.watier@inserm.fr

${ }^{1}$ Epidemiology and Modeling of bacterial Evasion to Antibacterials Unit (EMEA), Institut Pasteur, 25-28, Rue du Dr. Roux, 75724 Paris Cedex 15, France

${ }^{2}$ Center for Research in Epidemiology and Population Health (CESP), INSERM U1018, Paris-Saclay University, UVSQ, Montigny-Le-Bretonneux, France Full list of author information is available at the end of the article
}

Additional file 1: Supplement S1: Database description and patient selection. Table S1: ICD-10 codes used. Table S2: Selected bacteria included and associated resistance markers. Supplement S2: Algorithms for identification of risk factors. Table S3: Code list for definition of potential risk factors. Table S4: Conditional univariate logistic regression: Risk factors of having a community-acquired or healthcare-associated urinary tract infection caused by a resistant bacterium compared with a susceptible one, by gender. Table S5: Number of antibiotic dispensing during the previous 3 months. Table $\mathbf{S 6}$. Characteristics of patients excluded and included for analysis of association between antibiotic classes and resistant-bacterial acquisition.

\section{Author details}

${ }^{1}$ Epidemiology and Modeling of bacterial Evasion to Antibacterials Unit (EMEA), Institut Pasteur, 25-28, Rue du Dr. Roux, 75724 Paris Cedex 15, France. ${ }^{2}$ Center for Research in Epidemiology and Population Health (CESP), INSERM U1018, Paris-Saclay University, UVSQ, Montigny-Le-Bretonneux, France. ${ }^{3}$ AP-HP, Paris Saclay, Public Health, Medical Information, Clinical Research, Le Kremlin-Bicêtre, France. ${ }^{4}$ French National Health Insurance (Cnam), 50 Avenue du Pr-André-Lemierre, 75986 Paris Cedex 20, France.

Published online: 29 June 2021

\section{Reference}

1. Opatowski $\mathrm{M}$, et al. Antibiotic prescriptions and risk factors for antimicrobial resistance in patients hospitalized with urinary tract infection: a matched case-control study using the French health insurance database (SNDS). BMC Infect Dis. 2021;21:571 https://doi.org/10.1186/s12879-021-06287-1.

C C The Author(s). 2021 Open Access This article is licensed under a Creative Commons Attribution 4.0 International License, which permits use, sharing, adaptation, distribution and reproduction in any medium or format, as long as you give appropriate credit to the original author(s) and the source, provide a link to the Creative Commons licence, and indicate if changes were made. The images or other third party material in this article are included in the article's Creative Commons licence, unless indicated otherwise in a credit line to the material. If material is not included in the article's Creative Commons licence and your intended use is not permitted by statutory regulation or exceeds the permitted use, you will need to obtain permission directly from the copyright holder. To view a copy of this licence, visit http://creativecommons.org/licenses/by/4.0/ The Creative Commons Public Domain Dedication waiver (http://creativecommons.org/publicdomain/zero/1.0/) applies to the data made available in this article, unless otherwise stated in a credit line to the data. 